\title{
Bessarabian (Tortonian, Late Miocene) fish otoliths from a transitional freshwater-brackish environment of Mykhailivka, Southern Ukraine
}

\author{
Andriy Bratishko, Oleksandr Kovalchuk, and Werner Schwarzhans
}

\begin{abstract}
The Mykhailivka sedimentary section in southern Ukraine of middle (Bessarabian) to late (Khersonian) Sarmatian s.l. age is well known for its rich vertebrate finds in alternating marginal marine to estuarine and lacustrine environments. Here we describe fish otoliths obtained from sediments from a supposedly estuarine environment that had already yielded fossil fish bones and teeth described earlier. The otolith association is dominated by three species of gobiids, which are all related to the endemic extant Ponto-Caspian gobiid fauna. One species - Neogobius bettinae n. sp. - is described here. Rare associated species are Morone cf. nobilis, so far only known from the North Sea Basin, and a sciaenid. All otolith-based species represent euryhaline groups of fishes that are known today to commonly migrate from marine into brackish waters or are adapted to brackish and freshwater environments.
\end{abstract}

Andriy Bratishko. Faculty of Natural Sciences, Luhansk Taras Shevchenko National University, 1 Gogolya Sqr., Starobilsk, 92703, Luhansk region, Ukraine; BugWare, Inc., 1615 Village Square Blvd, ste. 8, Tallahassee, FL 32309, U.S.A. andrejbratishko@mail.ru

Oleksandr Kovalchuk. Department of Paleontology, National Museum of Natural History of the National Academy of Sciences of Ukraine, 15 Bogdan Khmelnytsky str., Kyiv 01030, Ukraine. biologiest@ukr.net Werner Schwarzhans. Zoological Museum, Natural History Museum of Denmark, 15 Universitetsparken, Copenhagen 2100, Denmark. wwschwarz@aol.com

Keywords: bony fishes; Bessarabian; Miocene; Ukraine; Eastern Paratethys; new species

Submission: 22 March 2017 Acceptance: 31 August 2017

http://zoobank.org/91D1F9A1-D4E4-4D51-811E-4AD9FAEB798F

Bratishko, Andriy, Kovalchuk, Oleksandr, and Schwarzhans, Werner. 2017. Bessarabian (Tortonian, Late Miocene) fish otoliths from a transitional freshwater-brackish environment of Mykhailivka, Southern Ukraine. Palaeontologia Electronica 20.3.44A: 1-13 palaeo-electronica.org/content/2017/1990-tortonian-otolihs-from-ukraine

Copyright: September 2017 Palaeontological Association. This is an open access article distributed under the terms of AttributionNonCommercial-ShareAlike 4.0 International (CC BY-NC-SA 4.0), which permits users to copy and redistribute the material in any medium or format, provided it is not used for commercial purposes and the original author and source are credited, with indications if any changes are made.

creativecommons.org/licenses/by-nc-sa/4.0/ 


\section{INTRODUCTION}

During the Middle Miocene the Paratethys ocean became gradually isolated from the world oceans with only transient connectivity (Rögl, 1998). The Central and Eastern Paratethys seas were interconnected during short-lived transgressive events in the Konkian (late Badenian) and Early Sarmatian (Volhynian) during which times fully marine conditions prevailed, while the increasing degree of separation overall triggered a gradually decreasing of salinity (Popov et al., 2004; Ilyina, 2006; Ter Borgh et al., 2014). During the Late Miocene, a restricted marine environment continued to prevail in the Eastern Paratethys while the Central Paratethys developed into the brackish / freshwater Pannonian Sea (Popov et al., 2004).

Here we describe otoliths from a mixed riverine / marginal marine environment from the
Bessarabian, Middle Sarmatian s.I. (Tortonian) of Mykhailivka, Southern Ukraine, which during that time was located near the northwestern edge of the former Eastern Paratethys (Figure 1). The fish fauna is composed of pharyngeal teeth of ostariophysans, as well as jaw teeth and bones of other freshwater fishes described earlier by Kovalchuk (2015), and non-ostariophysan otoliths described here. The otolith assemblage contains five species belonging to four genera in three families: Moronidae, Sciaenidae, and Gobiidae. In the sampled interval, the fish fossils were associated with marine and non-marine molluscs as well as terrestrial mammal remains indicating the mixed nature of the sedimentary environment (Prisyazhniuk et al., 2006). It is one of the few freshwater to brackish otolith-based fish faunas known from the early to middle Sarmatian s.l. and equivalents of the Paratethys (Weinfurter, 1952, 1954; Rückert-
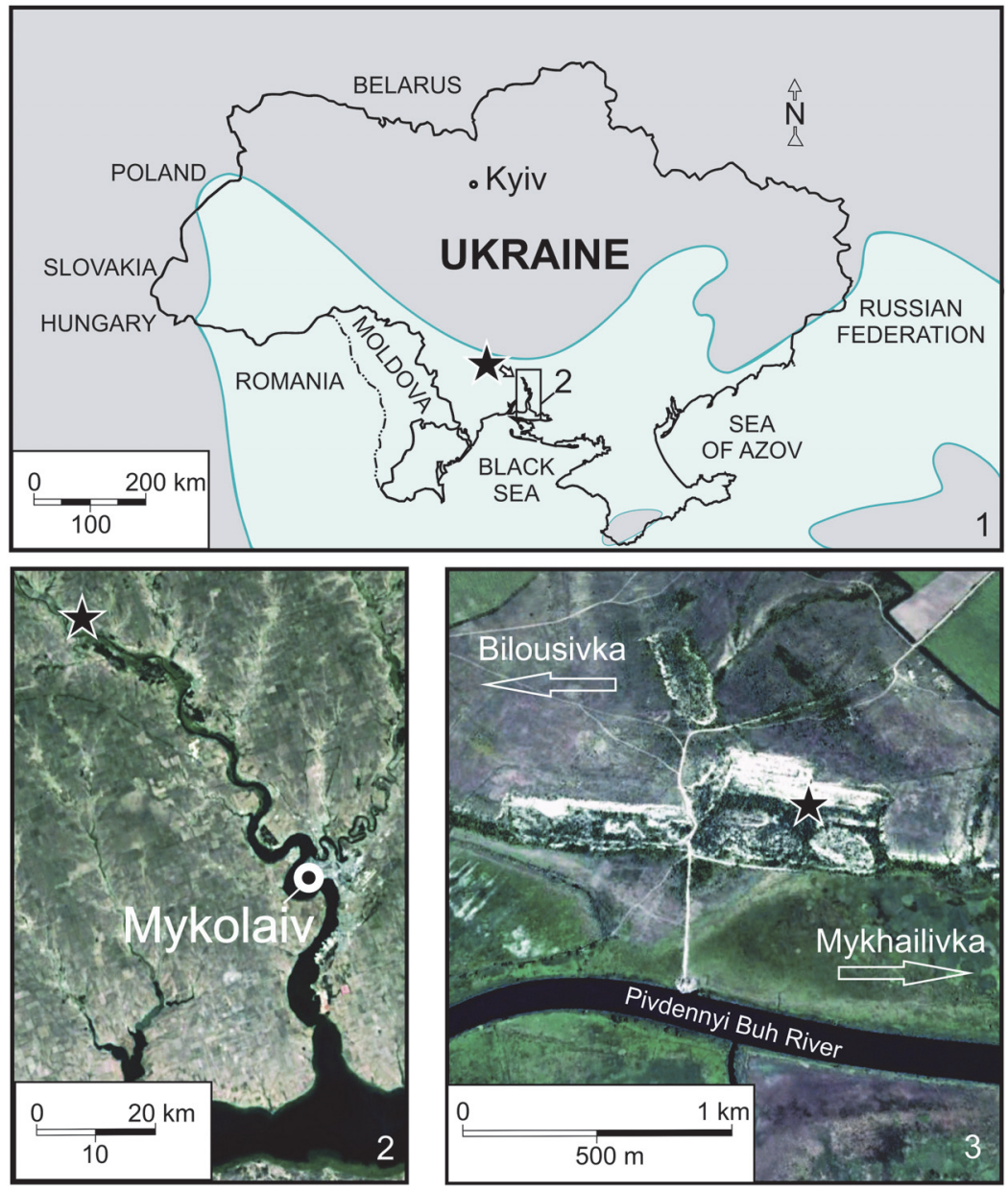

FIGURE 1. Map of Ukraine with the coastline of Eastern Paratethys (blue line) during the late middle Sarmatian s.l. (according to Popov et al., 2004) (1), enlargered part of the lower reaches of the Pivdennyi Buh River (2), location map of the Mykhailivka quarry (3). The Mykhailivka locality is marked by an asterisk. 
Ülkümen, 1996; Rückert-Ülkümen et al., 1993, 2006). Other coeval otolith associations stem from marine or restricted marine environments, e.g., Weiler (1943), Pobedina (1954), Strashimirov (1984, 1985), and Djafarova (2006). The same is true for fish faunas based on articulated skeletons, sometimes with otoliths in situ, e.g., Carnevale et al. (2006), Bannikov (2010), Bannikov and Kotlyar (2015), Schwarzhans et al. (2017a, 2017b, 2017c).

Here we apply the term "Sarmatian s.l." (Hilgen et al., 2012) to indicate the Sarmatian of the Eastern Paratethys, and we use the traditional terms "Bessarabian" and "Khersonian" which are Middle and Upper Sarmatian, accordingly (Muratov and Nevesskaya, 1986).

\section{Geological Setting}

The studied fish remains were collected in the northern Mykhailivka quarry $\left(47^{\circ} 39^{\prime} 06.75^{\prime \prime} \mathrm{N}\right.$, $\left.31^{\circ} 57^{\prime} 10.09 " \mathrm{E}\right)$ on the left bank of the Pivdennyi Buh River near the village of Mykhailivka (Mykolaiv region, Southern Ukraine) (Figure 1). This quarry has been well known for its fossil content since the late 1970s (Gozhik and Prisyazhniuk, 1978 - gastropods; Prisyazhniuk and Kovalenko, 2002 bivalves, gastropods and ostracods; Topachevsky et al., 1997; Nesin and Nadachowski, 2001, Nesin, 2013 - all dealing with small mammals). Prisyazhniuk et al. (2006) provided a detailed description of the profile including taxonomic, ecological, and stratigraphic information based on bivalves, gastropods, nannofossils, and spore-pollen assemblages. Accordingly, the Miocene sequence starts with a middle Sarmatian s.l. coquina unconformably overlying Eocene carbonates. The section is about $35 \mathrm{~m}$ thick and composed of clays and siltstones, with minor interbedded limestones and sands, and comprises seven transgressive-regressive cycles (Figure 2). Each cycle begins with a thin nearshore marine or lagoonal phase, often carbonate and oolitic in nature, overlain by a succession of riverine and lacustrine freshwater and terrestrial root-bearing beds. Prisyazhniuk et al. (2006) gave a detailed account of the changing faunal composition of lamellibranchiates (Mactra beds in the marine zone), gastropods, ostracods, and plant remains. The environmental setting is interpreted here as a coastal lowland close to the Sarmatian Sea. Small low energy rivers crossed the plain and entered to the sea possibly in small estuaries, since there are no indications of channelized or river bar bedding structures. The individual cycles could represent phases of minor sea level fluctuations as would be expected in an enclosed basin, similar to the modern Caspian Sea. The stratigraphical correlation is mainly based on mollusc and ostracod data, as well as on the recognition of the mammal zones $\mathrm{MN} 10$ and MN11, and comprises the stratigraphic interval from the upper Bessarabian (upper middle Sarmatian s.l.) to the lower Khersonian (lower upper Sarmatian s.l.) (Prisyazhniuk et al., 2006; Kovalenko, 2012; see Figure 2).

The fish otoliths described here were collected from the lower part of the section (layers 6-9 $=$ M.1 = Mykhailivka 1; Figure 2). This represents a level particularly rich in mammal fossils and an unusual mixture of marine and freshwater taxa (Prisyazhniuk et al., 2006), and may represent a short-lived estuarine environment in our assessment. Pharyngeal teeth of carp fishes (Ostariophysi) and fish bones of other freshwater fishes obtained from this level (M.1) as well as a higher level in the section (layer $25=$ M.2 = Mykhailivka 2) were studied by Kovalchuk (2015). The small mammal fossils facilitated a stratigraphic assignment of M.1 to the mammal zone MN10, and of M.2 to the mammal zone MN11 (Topachevsky et al., 1997; Nesin, 2013), which is consistent with the ages based on molluscs and ostracods. However, nannofossils from layer 15 have been determined as NN 8 (Prisyazhniuk et al., 2006). Thereby the nannoplankton is somewhat older than MN 10 (see Hilgen et al., 2012 for details) and in our view it could be a reworked assemblage.

\section{MATERIAL AND METHODS}

The studied screen-washed material was collected by V. Topachevsky, L. Rekovets, and V. Nesin (National Museum of Natural History, National Academy of Sciences of Ukraine, Kyiv) during their field campaigns in the 1980s. About $700 \mathrm{~kg}$ of sediments from M.1 were processed using a $1 \mathrm{~mm}$ mesh. Among many other fossils, the residue also contained thirty otoliths. The collection is housed in the Department of Paleontology, National Museum of Natural History NAS of Ukraine, Kyiv; acronym NMNHU-P. The ichthyological systematics in this paper follows Nelson (2006). The identification of otoliths is based on the literature and comparative collections of one of us (Werner Schwarzhans) and specimens in the National Museum of the Natural History NAS of Ukraine no. 2532, Zoological Museum of Moscow University (ZMMU) and Weinfurter's (1954) collection housed in the Department for Earth and Environmental Sciences, Palaeontology and Geobiology, Ludwig-Maximilians-Universität 


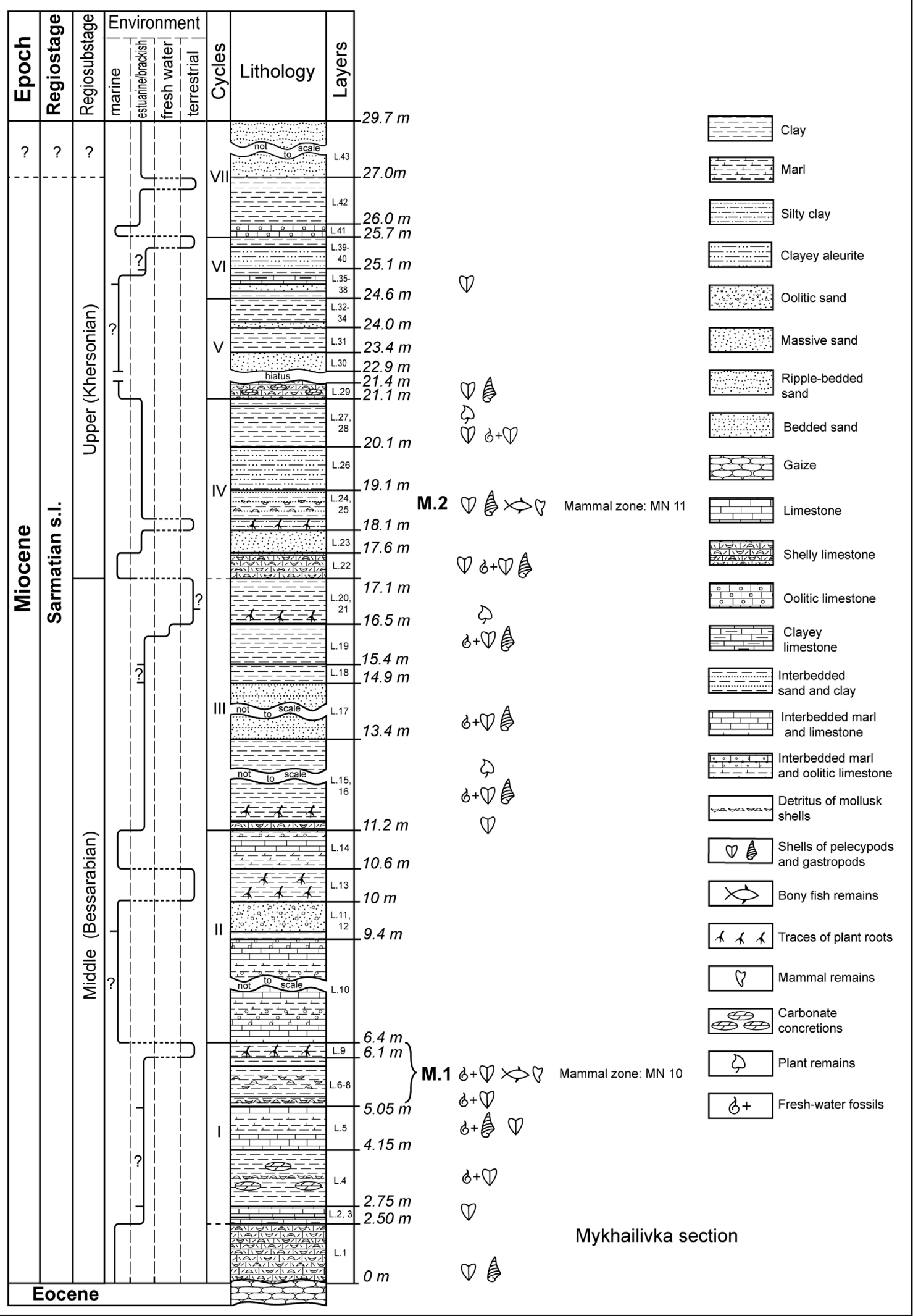

FIGURE 2. Stratigraphical position of the Mykhailivka section. Lithological and paleontological data from Prisyazhniuk et al. (2006). Reconstruction of environmental log deduced from Prisyazhniuk et al. (2006). 
München (Germany). Photographs of otoliths were taken with a Leica M 165 FC stereomicroscope in the Department for Earth and Environmental Sciences, Palaeontology and Geobiology, LudwigMaximilians-Universität München. Terminology of otoliths follows Koken (1891), Weiler (1942) and Schwarzhans (1978, 2014). Abbreviations used: otolith length $=\mathrm{OL}$, otolith height $=\mathrm{OH}$.

\section{SYSTEMATIC PALAEONTOLOGY}

Family MORONIDAE Jordan and Evermann, 1896 Genus MORONE Mitchill, 1814

Morone cf. nobilis (Koken, 1891)

Figure 3.1-4

1891 Otolithes (Dentex) nobilis; Koken, pl. 8, fig. 8.

1977 Morone limburgensis (Posthumus, 1923); Nolf, pl. 14, figs. 4-6.

1977 Acropoma nobilis (Koken, 1891); Nolf, pl. 15, figs. 21-22; pl. 18, figs. 3-4.

1994 Morone nobilis (Koken, 1891); Schwarzhans, figs. 373-388.

1996 Acropoma nobilis (Koken, 1891); Müller, pl. 5, fig. 7; pl. 7, figs. 17-18.

2009 Morone nobilis (Koken, 1891); Schwarzhans and Wienrich, pl. 199, figs. 4-6.

2010 Morone nobilis (Koken, 1891); Schwarzhans, pl. 73, figs. 6-12.

2013 Acropoma nobilis (Koken, 1891); Nolf, pl. 208.

Material. Two incomplete otoliths and one fragment (NMNHU-P 33/1482-1484, Mykhailivka 1).

Description. Otoliths are rather large (up to greater than $5 \mathrm{~mm}$ length). The anterior part of the ostium is damaged. The ventral rim is smooth and deeply curved, especially in the largest specimen (see Figure 3.1). The dorsal rim bears an anterodorsal and a distinct postero-dorsal angle. The posterior tip is slightly rounded.

The inner face is convex; the outer face is slightly concave. The sulcus is situated slightly supramedian and is moderately deepened. The ostium is incomplete, but certainly was shorter than the cauda and is about twice as wide, and dorsally and ventrally expanded. The cauda is straight anteriorly, bent downward posteriorly and terminates at some distance from the posteroventral rim. The crista superior is distinct and sharp; the crista inferior is poorly expressed.

Remark. Morone nobilis is known from the late Oligocene and early to middle Miocene of the North Sea Basin (e.g., Koken, 1891; Schwarzhans, 2010). The specimens presented here are very similar, but are assigned to $M$. nobilis with some reservation because of their incompleteness and the remoteness of the location from the North Sea Basin.

Family SCIAENIDAE Cuvier, 1829

Genus GENYONEMUS Gill, 1861

Genyonemus? sp.

Figure 3.5-8

Material. Two otoliths (NMNHU-P 33/1485, 1512, Mykhailivka 1).

Description. The elongate otolith is about $5 \mathrm{~mm}$ long, but its posterior part is not preserved. The ventral rim is smooth and anteriorly curved. The anterior tip is rounded. The dorsal rim is curved and slightly serrated with a broad median lobe, which is also slightly crenulated.

The inner face is faintly convex. The anterior part of the outer face is slightly concave and ornamented with many short radial furrows, while the posterior part is thickened and slightly convex. The sulcus is shallow with the cauda slightly deeper than the ostium. The ostium is three times wider than the cauda and is widened both dorsally and ventrally. The cauda terminates very close to the anterior rim of the otolith. The cauda is straight, only slightly bent posteriorly when approaching the posteroventral rim of the otolith. The crista superior is distinct.

Comparison. This otolith is very similar to the holotype of "genus aff. Genyonemus" pertenuis Müller, 1999 from the lower/middle Miocene of Eastern USA (Müller, 1999). It differs in the narrower cauda and more expressed postostial lobe. Rückert-Ülkümen (1996) described Serranus acuterostratus from Turkey, which may belong to the same genus as the ones from Mykhailivka. Our specimen, however, differs from Genyonemus? acuterostratus (Rückert-Ülkümen, 1996) in its anterior part being less elongate.

Family GOBIIDAE Cuvier, 1816

Genus PONTICOLA Iljin, 1927

Ponticola dorsorostralis (Weinfurter, 1954)

Figure 3.9-18

1954 Gobius dorsorostralis nov. spec.; Weinfurter, pl. 6, figs. 49-50.

1954 Gobius dorsorostralis sculpta n. sp., n. ssp.; Weinfurter, pl. 6, figs. 51-52.

1992 Gobius sp., aff. Gobius dorsorostralis Weinfurter, 1954; Brzobohatý, pl. 1, fig. 2.

2010 Gobius dorsorostralis Weinfurter, 1954; Schwarzhans, pl. 103, figs. 2-4.

2013 Gobius dorsorostralis Weinfurter, 1954; Nolf, pl. 320.

2014 Gobius dorsorostralis Weinfurter, 1954; Schwarzhans, pl. 8, figs. 1-2. 


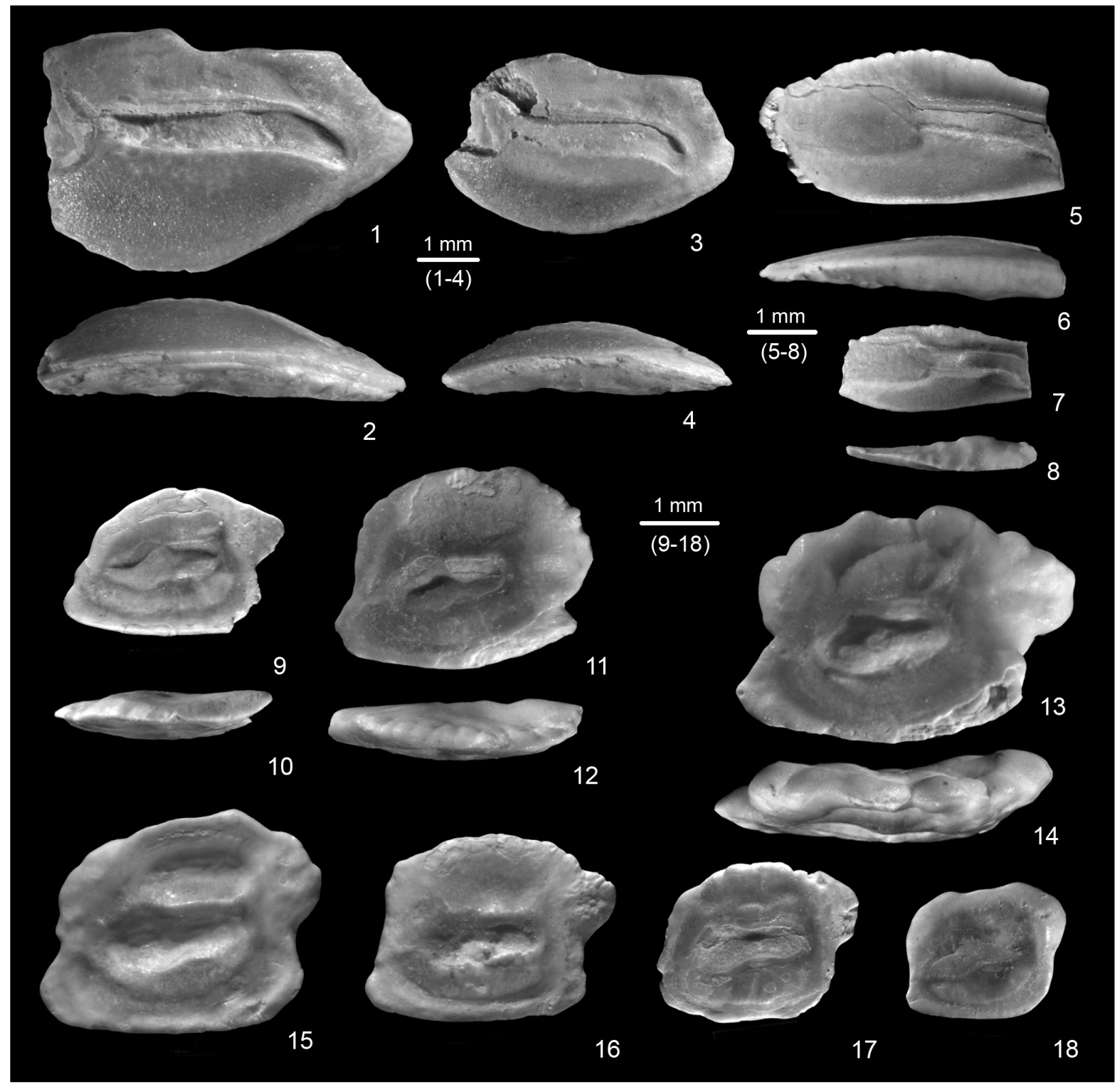

FIGURE 3. Otoliths from the Sarmatian s.I. of the Mykhailivka 1. 1-4, Morone cf. nobilis (Koken, 1891): NMNHU-P 33/ 1482, inner face (1), ventral view (2); NMNHU-P 33/1483, inner face (3), ventral view (4). 5-8, Genyonemus? sp.: NMNHU-P 33/1485, inner face (5), ventral view (6); NMNHU-P 33/1512, inner face (7), ventral view (8). 9-18, Ponticola dorsorostralis (Weinfurter, 1954): NMNHU-P 33/1486, inner face (9), ventral view (10); NMNHU-P 33/1487, inner face (11), ventral view (12); NMNHU-P 33/1488, inner face (13), ventral view (14); NMNHU-P 33/1489, inner face (15); NMNHU-P 33/1490, inner face (16); NMNHU-P 33/1491, inner face (17); NMNHU-P 33/1492, inner face (18). Scale bars equal $1 \mathrm{~mm} .5-10,17,18$ are mirrored.

2014 Gobius aff. dorsorostralis Weinfurter, 1954; Schwarzhans, pl. 8, fig. 3.

Material. Ten otoliths (NMNHU-P 33/1486-1495, Mykhailivka 1).

Description. The rectangular otoliths are moderately elongate. Sizes range from 3 to $5 \mathrm{~mm}$ in length. $\mathrm{OL}: \mathrm{OH}=1.35-1.5$. The anterior and posterior rims are inclined, slightly rounded, or straight.
They have pronounced anterodorsal and posteroventral angles. The dorsal rim is slightly curved and intensely but irregularly undulating or sometimes deeply crenulated. The otoliths have a well-developed rounded (pointed in juveniles) posterodorsal projection. The ventral rim is nearly flat, and smooth with a well-expressed slightly pointed anteroventral projection. The otoliths are thin. The 
inner face is slightly convex. The sulcus is soleshaped with a gently pointed tip of the ostium. The latter is wider and longer than the cauda, although the distinction is fluent. There is no subcaudal iugum. The ventral furrow is well-expressed. Adult specimens, have a distinct dorsal depression. The outer face is slightly concave with some ornamentation and protuberances.

Comparison. This species is similar to several extant species of Ponticola in otolith shape and the lack of a subcaudal iugum (see Vasilieva et al., 2016). It is best recognized by the intensely ornamented dorsal rim and the moderate index of $\mathrm{OL}: \mathrm{OH}$.

\section{Genus NEOGOBIUS Iljin, 1927 Neogobius bettinae n. sp.}

Figure 4.1-9

\section{zoobank.org/8586BCCF-E03C-48C1-9741-737E406D564B}

Etymology. In honour of Bettina Reichenbacher (Munich, Germany) for her great contribution to the knowledge of fossil fish faunas, particularly freshwater fishes and gobioids.

Type material. Holotype: NMNHU-P 33/1496 (Figure 4.5-6). Paratypes: seven specimens NMNHUP 33/1497-1503 (Figures 4.1-4, 4.7-9), Mykhailivka 1.

Type locality. Mykhailivka village, Mykolaiv region, Southern Ukraine.

Diagnosis. Compact otoliths with low anterodorsal rim and posteriorly elevated, rounded dorsal rim. Posterodorsal projection short, wide and rounded. Anteroventral projection weak or lacking. Sulcus with characteristic tip positioned just anterior to the junction of ostium and cauda. Otoliths rather thick $(\mathrm{OH}: \mathrm{OT}=2.0-2.2)$.

Description. The thick massive otoliths range from 1.5 to $4.5 \mathrm{~mm}$ in length. $\mathrm{OL}: \mathrm{OH}=1.16-1.23 ; 1.07$ (in juveniles). The anterior rim is short with a weak or absent anteroventral projection. The posterior rim is vertical and can be incised beneath the posterodorsal projection. The dorsal rim is highly elevated posteriorly, curved and slightly undulating; the anterodorsal angle is very low. These otoliths have a broad, rounded posterodorsal projection, which gently bends outwards. The ventral rim is smooth and straight with a rounded posterodorsal angle. The inner face is gently convex. The deep sulcus is inclined and sole-shaped. The tips of the sulcus are rounded. The ostium is wider than the cauda and displays a distinct and often pointed lobe at the dorsal rim. Some specimens (Figures $4.1,4.3,4.5)$ have a faint and narrow subcaudal iugum, but in most instances it is missing. The crista superior is more pronounced than the crista inferior. The ventral line is distinct. The dorsal depression is broad, distinct and rather deep in several specimens (e.g., Figures 4.5, 4.9). The outer face is slightly convex, with the greatest convexity at the long axis.

Comparison. Similar otoliths, showing the same characteristic tip of the ostial lobe, have been described from the middle Sarmatian of Azerbaijan as Gobius pricaspicus Pobedina, 1956 (see Pobedina et al., 1956, pl. 23, figure 4). Otoliths from the Mykhailivka locality are clearly different from those by having less crenulated rims, a depressed anterodorsal angle, and a distinctly longer sulcus. The faint or absent subcaudal iugum and the rather compressed shape with a low OL:OH index resembles Recent otoliths of the genus Neogobius. Otoliths of all extant species are figured here (Figure $5)$ for comparison [Neogobius caspius (Eichwald, 1831) (Figure 5.7-9), N. fluviatilis (Pallas, 1814) (Figure 5.5-6), N. melanostomus (Pallas, 1814) (Figure 5.1-2) and N. pallasi (Berg, 1916) (Figure 5.3-4)]. In the Recent species, N. melanostomus exhibits a clear subcaudal iugum, whereas in the other species it is either totally lacking or occasionally faint and indistinct as in $N$. bettinae. Neogobius fluviatilis and $N$. pallasi most closely resemble $N$. bettinae. However, $N$. bettinae is distinguished from the Recent species as well as the two fossil ones so far known ( $N$. rhachis Rückert-Ülkümen, 1993 in Rückert-Ülkümen et al., 1993 and N. udovichenkoi Bratishko, Schwarzhans and Reichenbacher, 2015 [in Bratishko et al., 2015]) by the high postdorsal rim, the relatively short and broad postdorsal projection and the rather thick appearance $(\mathrm{OH}: \mathrm{OT}=2.0-2.2)$. Otoliths of extant Gobius species all show a distinct and broad subcaudal iugum except faint in Gobius cobitis and G. paganellus, which however have very slender otoliths. Neogobius bettinae differs from $N$. rhachis by the low anterodorsal angle and curved dorsal rim (vs. rather flat). Both species occur together in Mykhailivka, indicating an already advanced speciation of the genus in the Ponto-Caspian Basin, possibly including extinct lineages (see also Schwarzhans et al., 2017c).

Neogobius rhachis Rückert-Ülkümen, 1993 in Rückert-Ülkümen et al., 1993

Figure 4.10-19

1993 Neogobius rhachis n. sp.; Rückert-Ülkümen et al., pl. 5, figs. 4-9.

2009 Neogobius rhachis Rückert-Ülkümen, 1993; Çevik Üner and Özkar Öngen, pl. 4, fig. 3.

Material. Eight otoliths (NMNHU-P 33/1504-1511, Mykhailivka 1). 


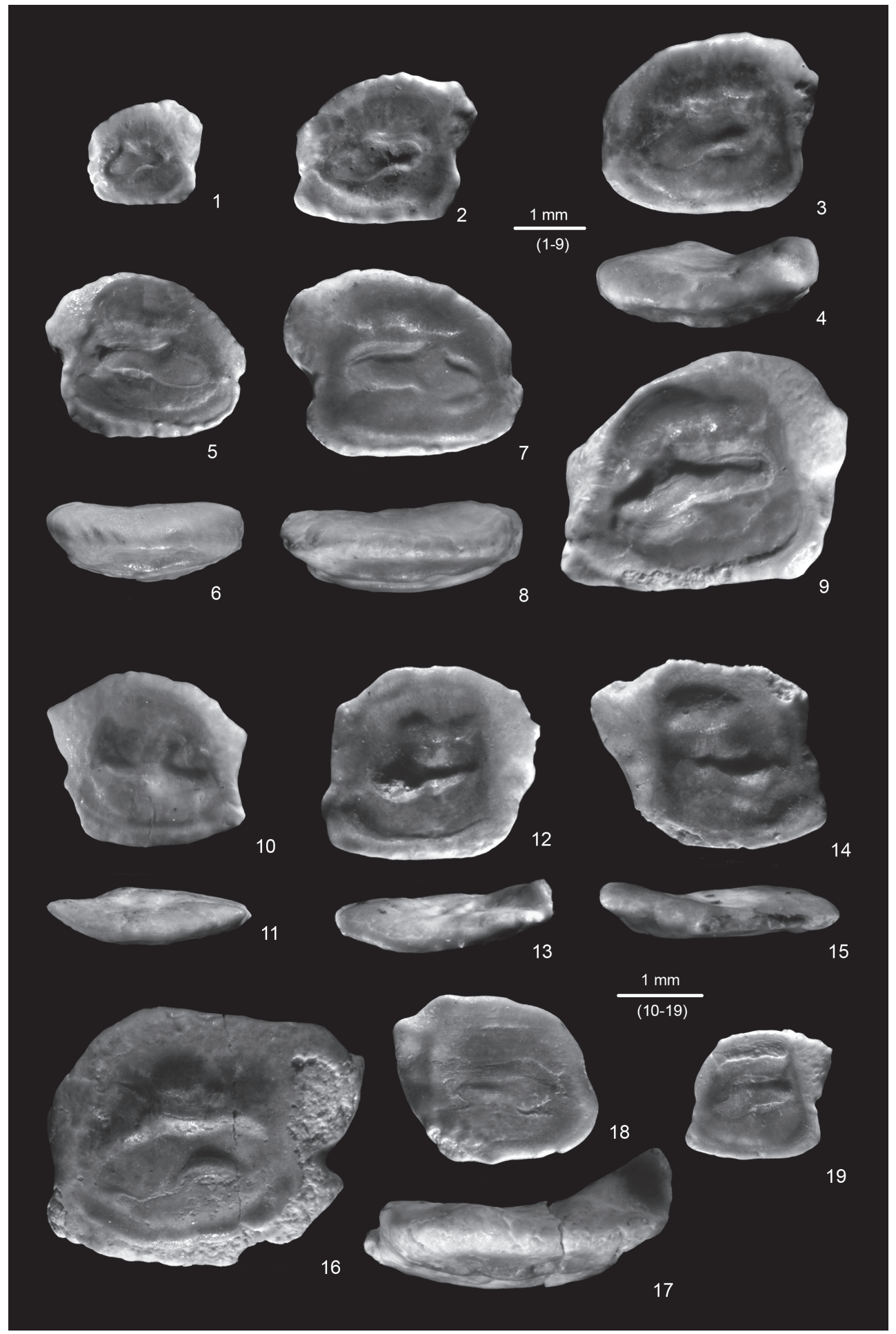

FIGURE 4. Otoliths from the Sarmatian s.I. of the Mykhailivka 1. 1-9, Neogobius bettinae n. sp.: NMNHU-P $33 / 1497$ (paratype), inner face (1); NMNHU-P 33/1498 (paratype), inner face (2); NMNHU-P 33/1499 (paratype), inner face (3), ventral view (4); NMNHU-P 33/1496 (holotype), inner face (5), ventral view (6); NMNHU-P 33/1500 (paratype), inner face (7), ventral view (8); NMNHU-P 33/1501 (paratype), inner face (9). 10-19, Neogobius rhachis Rückert-Ülkümen, 1993 in Rückert-Ülkümen et al., 1993: NMNHU-P 33/1504, inner face (10), ventral view (11); NMNHU-P 33/1505, inner face (12), ventral view (13); NMNHU-P 33/1506, inner face (14), ventral view (15); NMNHU-P 33/1507, inner face (16), ventral view (17); NMNHU-P 33/1508, inner face (18); NMNHU-P 33/1509, inner face (19). Scale bars equal $1 \mathrm{~mm}$. $5-$ $8,10,11,14,15,18$ are mirrored. 


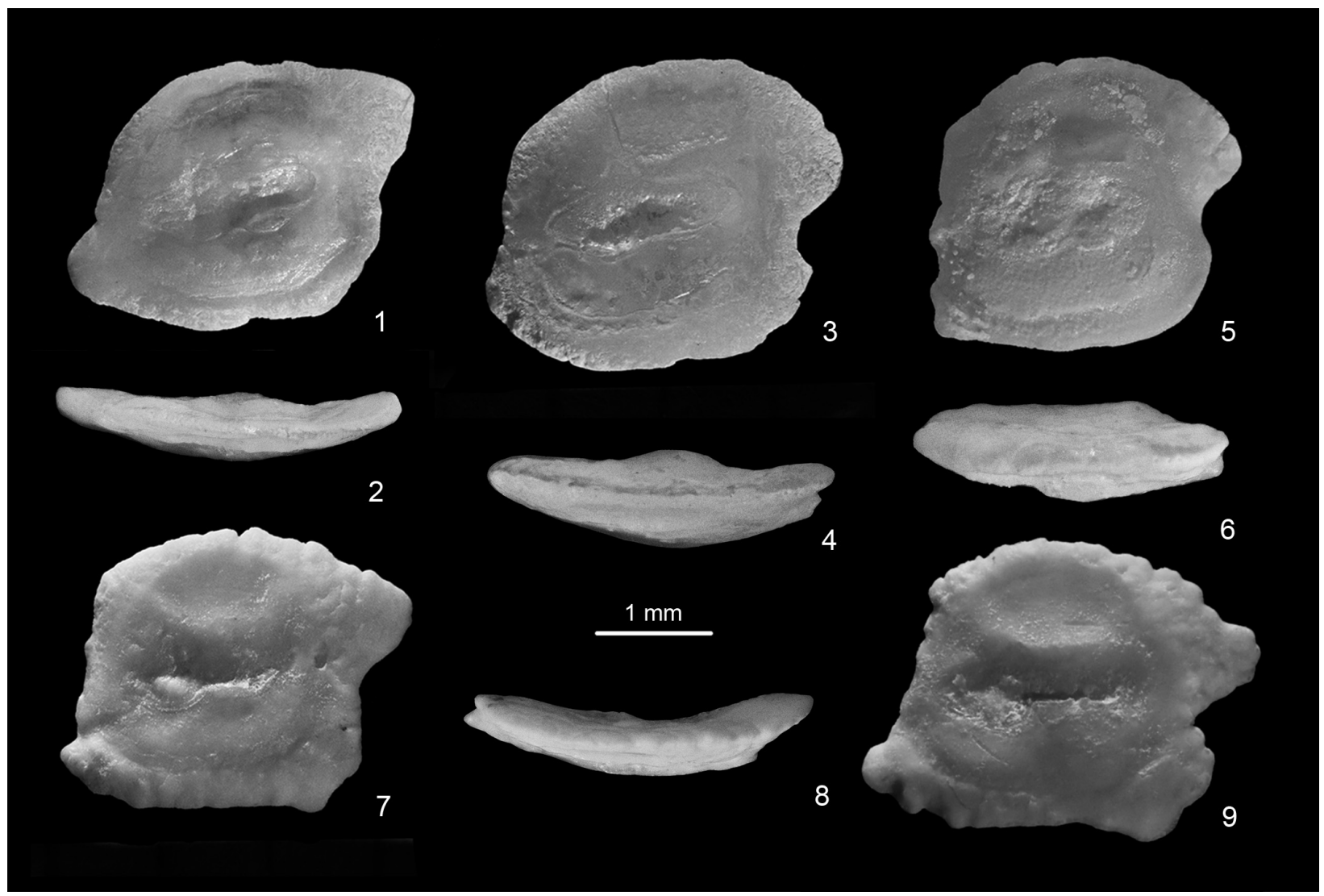

FIGURE 5. Recent otoliths of the genus Neogobius. 1-2, Neogobius melanostomus (Pallas, 1814): ZMMU, P.23515 3 , SL91, $43^{\circ} 38^{\prime} \mathrm{N}-51^{\circ} 08^{\prime} \mathrm{E}$, inner face (1), dorsal view (2). 3-4, Neogobius pallasi (Berg, 1916): ZMMU, P.23514, SL93, $43^{\circ} 28^{\prime} \mathrm{N}-51^{\circ} 18^{\prime} \mathrm{E}$., inner face (3), dorsal view (4). 5-6, Neogobius fluviatilis (Pallas, 1814): ZMMU, P.22433, SL81, $45^{\circ} 20^{\prime} \mathrm{N}-28^{\circ} 57^{\prime} \mathrm{E}$, inner face (5), dorsal view (6). 7-9, Neogobius caspius (Eichwald, 1831): 7-8, ZMMU, P.22622 1, SL90, 51 ${ }^{\circ} 25^{\prime} \mathrm{N}-46^{\circ} 03^{\prime} \mathrm{E}$, inner face (7), dorsal view (8); 9, ZMMU, P.22622 2, SL105, 51 ${ }^{\circ} 25^{\prime} \mathrm{N}-46^{\circ} 03^{\prime} \mathrm{E}$, inner face.

Description. These otoliths have a slightly tilted rectangular shape, and range in length from 2.0 to $3.5 \mathrm{~mm}$. OL:OH = 1.1-1.26; OH:OT = 3.3-3.4. The anterior and posterior rims are oblique and almost parallel to each other. The posterior rim is steep and has a slightly rounded posteroventral edge. The dorsal rim is slightly curved; the wide, nearly triangular posterodorsal projection is somewhat bent outwards. The ventral rim is smooth and flat or slightly curved.

The inner face is only slightly bent, primarily along the postdorsal projection. The sulcus is moderately deep. It is sole-shaped and usually shows no subcaudal iugum or only a very narrow and small one. The ostial tip is rather angled, the caudal tip rounded. The ventral furrow is distinct. The dorsal depression is broad and shallow.

The outer face is slightly concave, particularly at the outwardly bent postdorsal projection, and has short radial furrows near the rims. The otoliths are thinner along the dorsal part and increase in thickness towards the ventral part. The postdorsal projection is supported by a ridge on the outer face.

Comparison. Neogobius rhachis differs from $N$. udovichenkoi Bratishko, Schwarzhans, and Reichenbacher, 2015 from the Konkian of Mangyshlak (Kazakhstan) in having a more compressed outline expressed in the smaller index of $\mathrm{OL}: \mathrm{OH}(1.10-1.26$ vs 1.2-1.4) and shorter preventral and posterodorsal projections. The slightly oblique, parallel anterior and posterior rims represent a characteristic feature for $N$. rhachis as well as the ridge on the outer face supporting the postdorsal projection. Furthermore, N. rhachis is very similar to otoliths of the extant $N$. fluviatilis (Pallas, 1814) (Figure 5.5-6), which is common in the rivers flowing to the Azov and Black Seas (Froese and Pauly, 2016). Nevertheless, otoliths of the fossil species are thinner and have a more pronounced and bent posterodorsal projection. 


\section{DISCUSSION}

\section{Palaeoecological Analysis}

Fossils obtained from the marl-clayey deposits of the Mykhailivka 1 level (Figure 2) contain abundant freshwater molluscs (Anisus, Valvata, Hydrobia), and rare marine (Mactra) and terrestrial (Carychium, Vertigo, Gastrocopta) molluscs (Prisyazhniuk et al., 2006). Brackish ostracods (Cyprideis) dominate in Mykhailivka 1: layers 6, 7 have more than $80 \%$, and layer 8 has $45 \%$ (plus up to $50 \%$ of freshwater ostracods), while the portion of marine specimens is small (Prisyazhniuk et al., 2006). Pharyngeal teeth and bones of fishes are represented primarily by cyprinid genera in Mykhailivka 1: Scardinius, Palaeocarassius, Luciobarbus and Tinca. They are interpreted to be indicative of a river system with extensive small tributaries and with warm slowly-flowing low energy freshwater, with a muddy bottom and thickets of underwater vegetation (Kovalchuk, 2015). The entire sedimentary sequence at Mykhailivka was probably deposited near the former coast line of the Eastern Paratethys and is characterized by ephemeral shallow marine incursions, probably in an estuarine setting.

The fish otoliths studied here do not represent any of the fish groups represented by teeth or bones, but rather complement the faunal association. Otoliths have been identified representing three different families: Moronidae, Gobiidae and Sciaenidae. Morone is an anadromous, demersal fish, living in small shoals in coastal marine and estuarine habitats and is regularly invading nearby brackish and freshwater bodies. It is also known from quiet water areas of medium to large rivers with mud bottoms (Froese and Pauly, 2016).

The Gobiidae are an extremely diverse, widely distributed and successful shallow water marine, brackish and freshwater family with many euryhaline species (Froese and Pauly, 2016). Ponticola dorsorostralis is known from brackish deposits of the Pannonian (Tortonian) of the Vienna Basin (Weinfurter, 1954) and the Sarmatian s.s. (Serravallian) of Wiesen in Austria (Schwarzhans, 2010). Otoliths identified as Gobius aff. dorsorostralis from the Karaman Basin in Turkey were also recorded from brackish-marine deposits (Schwarzhans, 2014). Our material confirms the conclusion of Schwarzhans (2014) that $P$. dorsorostralis possibly was a non-marine species. Neogobius rhachis was originally described from the Sarmatian s.s. to Pannonian in freshwater to brackish environments of the southwestern part of the Eastern Paratethys in Western Turkey (Rückert-Ülkümen et al., 1993). Finally, Neogobius bettinae is here recorded for the first time. It is interpreted as related to the extant $N$. fluviatilis, which is a fresh- to brackish water species of the tributaries of the Ponto-Caspian Basin. All three gobiid species at Mykhailivka thus represent the endemic Ponto-Caspian goby group, which has adapted so successfully to the changing environments and water salinities of the basin since the Sarmatian times of the Paratethys (Schwarzhans et al., 2015, 2017c). None of these species has been recorded from the rich stenohaline marine gobiid faunas of the Sarmatian of the Paratethys. The Sciaenidae, finally, are well known for their adaptation to the warm shallow seas and estuaries of the world, both in the Recent (Trewavas, 1977) as well as the fossil record (Schwarzhans, 1993; Aguilera et al., 2016). Many of the species occurring in estuarine environments are also known to move up river into brackish and freshwaters (Aguilera et al., 2016).

We therefore conclude that the fish fauna from the Mykhailivka 1 level matches with a mixed - freshwater and brackish, probably estuarine environment, which was also favorable for anadromous species. Other paleontological data and the lithological sequence confirm a close proximity to a large marine basin, i.e., the Eastern Paratethys, in a riverine and estuarine setting with low to moderate energy.

The fossil assemblage of the Mykhailivka 2 level (Figure 2) did not contain otoliths. The basal level of the layer contains shells of marine, and freshwater, as well as terrestrial molluscs according to Prisyazhniuk et al. (2006). They also observed certain freshwater clams, i.e., Pseudohyriopsis and Potamoscapha, in vitro. The ostracod fauna from layers 22, 23, 25, and 26 (Figure 2) comprises variable amounts of marine (from $10 \%$ to $80 \%$ ) and brackish (from $20 \%$ to $80 \%$ ) taxa with minor (less than $5 \%$ ) numbers of freshwater specimens (Prisyazhniuk et al., 2006).

The fish assemblage of layer 25 contained pharyngeal teeth and bones (but no otoliths), which are all from typical freshwater fishes and could represent the next step in the development of the regional set-up located in the lower part of the river system at some distance from the sea. Kovalchuk (2015) interpreted the faunal elements to indicate the presence of nearby rapids with cold water (Chondrostoma, Luciobarbus), slowly flowing water (Esox), overgrown warm ponds (Palaeocarassius, Tinca), and backwaters (Silurus) all in the lower reaches of the river (Kovalchuk and Ferraris, 
2016). The reason for the absence of otoliths of these fishes from both Mykhailivka 1 and 2 is not yet understood. However, Mykhailivka 2 entirely lacks otoliths including any indication of moronid, goby, and sciaenid otoliths found in Mykhailivka 1.

\section{Palaeogeography and Biostratigraphy}

The limited amount of otolith-based taxa allows only a limited evaluation of the palaeogeography and biostratigraphy of Mykhailivka 1.

Morone cf. nobilis from Mykhailivka 1 is the first record of this species in the Eastern Paratethys, and it is probably also the youngest record of the species. Schwarzhans (2010) recorded Morone nobilis as common and widespread in the North Sea Basin, ranging from the Chattian to the lower Langenfeldian (late Serravallian). There are no earlier records of $M$. nobilis in the Central or the Eastern Paratethys despite a relatively good fossil otolith record. Therefore, its occurrence in Mykhailivka requires some sort of connectivity among these regions about which we feel unable at present to speculate. It should be noted, however, that Schwarzhans et al. (2017b) reported a case of a typical, putatively endemic Paratethyan gadid, Paratrisopterus caspius Bogatshov, 1929, possibly also occurring in the late Miocene of the North Sea Basin.

Neogobius rhachis clearly confirms the connections of the former Galician Gulf with the brackish/freshwater lakes of Western Anatolia (RückertÜlkümen et al., 1993; Popov et al., 2004). Ponticola dorsorostralis indicates the connectivity between the freshwater/brackish water regions of the Central and Eastern Paratethys during the middle Sarmatian s.l. Interestingly, the Mykhailivka 1 otolith assemblage does not have any species in common with the very rich coeval otolith-based fauna of Jurkino, Kerch Peninsula (Bratishko and Schwarzhans, unpublished data) despite the rather close proximity. From preliminary data, the Jurkino fish association is very rich in gobiids although these all represent different species from those of Mykhailivka. The reason for this faunal difference clearly is related to the difference in environment: fully marine, albeit with a somewhat reduced salinity at Jurkino, and riverine to estuarine at Mykhailivka.

The small fish fauna obtained from Mykhailivka thus represents a still rare window into the freshwater fish fauna of the Sarmatian / PontoCaspian borderland, one of the largest and most dynamic freshwater bioprovinces of Eurasia.

\section{ACKNOWLEDGEMENTS}

We are very grateful to $B$. Reichenbacher (Munich, Germany) for valuable discussion about the identification of otoliths and her hospitality and help during the research visit of the senior author in Munich. We extend our gratitude to L. Rekovets (Wrocław, Poland) and V. Nesin (Kyiv, Ukraine) for their effort in obtaining fossil materials. We would also like to thank V. Prisyazhniuk and V. Vernyhorova (Kyiv, Ukraine) for important and helpful consultations regarding the stratigraphy of the Sarmatian deposits. We express our thanks to E. Vasilieva (Moscow, Russia) for her hospitality and access to specimens of Recent gobies in Zoological Museum of Moscow State University. We are very thankful to A. Murray (Edmonton, Canada) for proofreading the text. We further wish to thank the executive editor J. Louys, the handling editor $\mathrm{K}$. Claeson, and the style editor C. Grohé for their effective management of our submission and the two anonymous reviewers for their constructive evaluation of the manuscript.

\section{REFERENCES}

Aguilera, O.A., Schwarzhans, W., and Béarez, P. 2016. Otoliths of the Sciaenidae from the Neogene of tropical America. Palaeo Ichthyologica, 14:7-90.

Bannikov, A.F. 2010. Fossil Acanthopterygian fishes (Teleostei, Acanthopterygii). GEOS, Moscow. (In Russian)

Bannikov, A.F. and Kotlyar, A.N. 2015. A new genus and species of early Sarmatian porgies (Perciformes, Sparidae) from the Krasnodar Region. Paleontological Journal, 49:627-635.

Berg, L.S. 1916. Ryby Presnyh vod Rossijskoj Imperii. Izdatel'stvo Departamenta zemledelija, Moscow. (In Russian)

Bratishko, A., Schwarzhans, W., Reichenbacher, B., Vernyhorova, Y., and Ćorić, S. 2015. Fish otoliths from the Konkian (Miocene, early Serravallian) of Mangyshlak (Kazakhstan): testimony to an early endemic evolution in the Eastern Paratethys. Paläontologische Zeitschrift, 89:839-889.

Brzobohatý, R. 1992. Otolithen aus dem Obermiozän, Pontien, des Wiener Beckens (Götzendorf und Stixneusiedl, NÖ). Annalen des Naturhistorischen Museums in Wien, Serie A, 94:1-6.

Carnevale, G., Bannikov, F.A., Landini, W., and Sorbini, C. 2006. Volhynian (early Sarmatian s.l.) fishes from Tsurevsky, North Caucasus (Russia). Journal of Paleontology, 80:684-699.

Çevik Üner, B. and Özkar Öngen, İ. 2009. Küçükçekmece (İstanbul) Sarmasiyen (Üst Miyosen) Balık Otolith'Lerinin İncelenmesi. İstanbul Yerbilimleri Dergisi, 2009:141-162. 
Cuvier, G. 1816. Le Règne Animal Distribué d'Après son Organisation, Pour Servir de Base à l'Histoire Naturelle des Animaux et d'Introduction à l'Anatomie Comparée. Tome II. Déterville, Paris.

Cuvier, G. 1829. Le Règne Animal Distribué d'Après son Organisation, Pour Servir de Base à l'Histoire Naturelle des Animaux et d'Introduction à l'Anatomie Comparée. Nouvelle édition rev. et aug, Tome II. Déterville, Paris.

Djafarova, J.D. 2006. Neogene Otoliths of Azerbaijan. Nafta-Press, Baku. (In Russian)

Froese, R. and Pauly, D. 2016. FishBase. www.fishbase.org.

Gill, T.N. 1861. Catalogue of the fishes of the eastern coast of North America, from Greenland to Georgia. Proceedings of the Academy of Natural Sciences of Philadelphia, 13 (Suppl.):1-63.

Gozhik, P.F. and Prisyazhniuk, V.A. 1978. Freshwater and Terrestrial Molluscs of the Miocene of RightBank Ukraine. Naukova Dumka, Kiev. (In Russian)

Hilgen, F.J., Lourens, L.J., and van Dam, J.A. 2012. The Neogene Period, p. 923-978. In Gradstein, F.M., Ogg J.G., Schmitz, M., and Ogg G. (eds.), The Geological Time Scale 2012. Elsevier, Boston. doi: 10.1016/B978-0-444-59425-9.00029-9.

Iljin, B.S. 1927. A guide to the gobies (family Gobiidae) of the Azov and Black seas. Trudy Azovsko-Chernomorskoj nauchno-promyshlennoj ekspeditsii, 2:128143. (In Russian)

Ilyina, L.B. 2006. Morphogenesis of Rissoidae in the inland basins of the Eastern Paratethys. Paleontological Journal, 4:54-63.

Jordan, D.S. and Evermann, B.W. 1896. The fishes of North and Middle America: a descriptive catalogue of the species of fish-like vertebrates found in the waters of North America, north of the Isthmus of Panama. Part I. Bulletin of the United States National Museum, 47:i-lx +1-1240.

Koken, E. 1891. Neue Untersuchungen an Tertiären Fisch-Otolithen II. Zeitschrift der Deutschen Geologischen Gesellschaft, 43:77-170.

Kovalchuk, A.N. [O.M.] 2015. Late Miocene Carp Fishes (Cyprinidae) of Southern Ukraine. Universytets'ka knyga, Sumy. (In Russian)

Kovalchuk, O.M. and Ferraris, C.J. 2016. Late Cenozoic catfishes of southeastern Europe with inference to their taxonomy and palaeogeography. Palaeontologia Electronica, 19(3.34A):1-17.

Kovalenko, V.A. 2012. Miocene ostracods from the eastern coast of the Sea of Azov. Reports of the National Academy of Sciences of Ukraine, 11:111-119. (In Russian)

Mitchill, S.L. 1814. Report, in Part, of Samuel L. Mitchill, M. D., Professor of Natural History, \&c, on the Fishes of New-York. D. Carlisle, New York.

Müller, A. 1996. Die Ichthyofauna des Oberoligozäns der Hessischen Senke (Raum Kassel, Deutschland). Leipziger Geowissenschaften, 2:31-115.
Müller, A. 1999. Ichthyofaunen aus dem atlantischen Tertiär der USA. Leipziger Geowissenschaften, 9/ 10:1-360.

Muratov, M.V. and Nevesskaya, L.A. 1986. Stratigraphy of the USSR. The Neogene System. Vol. 1. Nedra, Moscow. (In Russian)

Nelson, J.S. 2006. Fishes of the World. John Wiley and Sons Inc., New York.

Nesin, V.A. 2013. Neogene Murinae (Rodentia, Muridae) of Ukraine. Universytetska knyga, Sumy. (In Russian)

Nesin, V.A. and Nadachowski, A. 2001. Late Miocene and Pliocene small mammal faunas (Insectivora, Lagomorpha, Rodentia) of Southeastern Europe. Acta Zoologica Cracoviensia, 44:107-135.

Nolf, D. 1977. Les otolithes de téléostéens de l'OligoMiocène belge. Annales de la Sociéte Royale Zoologique de Belgique, 106:3-119.

Nolf, D. 2013. The Diversity of Fish Otoliths: Past and Present. Royal Belgian Institute of Natural Sciences, Brussels.

Pallas, P.S. 1814. Zoographia rosso-asiatica, sistens omnium animalium in extenso Imperio Rossico et adjacentibus maribus observatorum recensionem, domicilia, mores et descriptiones anatomen atque icones plurimorum. Vol. 3. Animalia monocardia seu frigidi sanguinis. Academia Scientarum, Petropolis.

Pobedina, V.M. 1954. Fossil fish otoliths from the Miocene deposits of Azerbaidzhan and their stratigraphic significance. Izvestia Akademii Nauk Azerbaidjanskoy SSR, 10:23-37. (In Russian)

Pobedina, V.M., Voroshilova, A.G., Rybina, O.I., and Kuznetsova, Z.V. 1956. Handbook of microfauna from middle and upper Miocene deposits of Azerbaidjan. Baku, Azerbaidjan. (In Russian)

Popov, S.V., Rögl, F., Rozanov, A.Y., Steininger, F.F., Shcherba, I.G., and Kovac, M. 2004. Lithologicalpaleogeographic maps of Paratethys. 10 maps from Late Eocene to Pliocene. Courier Forschungsinstitut Senckenberg, 250:1-46.

Posthumus, O. 1923. Bijdrage tot de kennis van de tertiaire visch-fauna van Nederland. Verhandelingen vat het Geologisch-Mijnbouwkundig Genootschap voor Nederland en Kolonien, Geologische Serie, 7:105142.

Prisyazhniuk, V.A. and Kovalenko, V.A. 2002. About advantage of integrated study of key sections of the Neogene of Ukraine (for example of the Mikhailovsky quarry section), p. 89-91. In Gozhik, P.F. (ed.), Organic Evolution as a Basis for Solving the Problems in Stratigraphy. Kiev, Russia. (In Russian)

Prisyazhniuk, V.A., Kovalenko, V.A., Liulieva, S.A., and Siabriay, S.V. 2006. Cross-section of Sarmatian deposits in the Mikhailovsky quarry - a unique point of the direct correlation of marine and continental sediments. Geological Journal, 1:64-75. (In Russian)

Rögl, F. 1998. Palaeogeographic considerations for Mediterranean and Paratethys seaways. Annalen des Naturhistorischen Museums in Wien, 99A:279310. 
Rückert-Ülkümen, N. 1996. Weitere Beiträge zur Otolithenfauna von Avcılar W Küçükçekmece See (Thrakien, Türkei). Mitteilungen der Bayerischen Staatssammlung für Paläontologie und Historische Geologie, 36:117-133.

Rückert-Ülkümen, N., Kaya, O., and Hottenrott, M. 1993. Neue Beiträge zur Tertiär-Stratigraphie und Otolithenfauna der Umgebung von Istanbul (Küçükçekmece- und Büyükçekmece See), Türkei. Mitteilungen der Bayerischen Staatssammlung für Paläontologie und Historische Geologie, 33:51-89.

Rückert-Ülkümen, N., Kowalke, T., Matzke-Karasz, R., Witt, W., and Yiğitbaş, E. 2006. Biostratigraphy of the Paratethyan Neogene at Yalova (Izmit-Province, NW-Turkey). Newsletters on Stratigraphy, 42:43-68.

Schwarzhans, W. 1978. Otolith-morphology and its usage for higher systematical units, with special reference to the Myctophiformes s.l. Mededelingen Werkgroep Tertiaire Kwartaire Geologie, 15:167-185.

Schwarzhans, W. 1994. Die Fisch-Otolithen aus dem Oberoligozän der Niederrheinischen Bucht. systematik, palökologie, paläobiogeographie, biostratigraphie und otolithen-zonierung. Geologisches Jahrbuch, 140:1-248.

Schwarzhans, W. 2010. The Otoliths from the Miocene of North Sea Basin. Backhuys, Leiden; Margraf, Weikersheim.

Schwarzhans, W. 2014. Otoliths from the middle Miocene (Serravallian) of the Karaman Basin, Turkey. Cenozoic Research, 14(1):35-69.

Schwarzhans, W., Bradić, K., and Rundić, Lj. 2015. Fishotoliths from the marine-brackish water transition from the Middle Miocene of the Belgrade area, Serbia. Paläontologische Zeitschrift, 89(4):815-837.

Schwarzhans, W., Carnevale, G., Bannikov, A.F., Japundžić, S., and Bradić, K. 2017a. Otoliths in situ from Sarmatian (Middle Miocene) fishes of the Paratethys. Part I: Atherina suchovi Switchenska, 1973. Swiss Journal of Palaeontology. doi: 10.1007/ s13358-016-0114-5.

Schwarzhans, W., Carnevale, G., Bratishko, A., Japundžić, S., and Bradić K. 2017b. Otoliths in situ from Sarmatian (Middle Miocene) fishes of the Paratethys. Part II: Gadidae and Lotidae. Swiss Journal of Palaeontology. doi: 10.1007/s13358-016-0114-5.

Schwarzhans, W., Ahnelt, H., Carnevale, G., Japundžić, S., Bradić, K., and Bratishko, A. 2017c. Otoliths in situ from Sarmatian (Middle Miocene) fishes of the Paratethys. Part III: tales from the cradle of the
Ponto-Caspian gobies. Swiss Journal of Palaeontology. doi: 10.1007/s13358-016-0120-7.

Schwarzhans, W. and Wienrich, G. 2009. Die Fauna des marinen Miozäns vor Kevelaer (Niederrhein). Otolithen, 5:953-1185.

Strashimirov, B. 1984. Otolity ot dolnia sarmat na Severnaia Bulgaria. Palaentology, Stratigraphy and Lithology, 20:15-41.

Strashimirov, B. 1985. Otolity ot srednia sarmat na Severnaia Bulgaria. Annual of the Highest Institute of Mining and Geology Sofia, 31:7-20.

Ter Borgh, M., Stoica, M., Donselaar, M.E., Matenco, L., and Krijgsman, W. 2014. Miocene connectivity between the Central and Eastern Paratethys: Constraints from the western Dacian Basin. Palaeogeography, Palaeoclimatology, Palaeoecology, 412:45-67.

Topachevsky, V.A., Nesin, V.A., and Topachevsky, I.V. 1997. An essay of the small mammal fauna history (Insectivora, Lagomorpha, Rodentia) in Ukraine during Middle Sarmat-Aktchagyl period. Vestnik zoologii, 31:3-14. (In Russian)

Trewavas, E. 1977. The sciaenid fishes (croakers or drums) of the Indo-West-Pacific. Transactions of the Zoological Society of London, 33:i-541.

Vasilieva, E.D., Schwarzhans, W.W., Medvedev, D.A., and Vasiliev, V.P. 2016. Cryptic species of PontoCaspian bighead goby of the genus Ponticola (Gobiidae). Journal of Ichthyology, 56:1-18.

von Eichwald, [C.] E. 1831. Zoologia specialis quam expositis animalibus tum vivis, tum fossilibus potissimum Rossiae in universam, et Poloniae in specie, in usum lectionum publicarum in universitate caesarea vilnensi habendarum. Pars posterior specialem expositionem spondylozoorum continens. Jozeph Zawadski publ., Vilna.

Weiler, W. 1942. Die Otolithen des rheinischen und nordwestdeutschen Tertiärs. Abhandlungen des Reichsamts für Bodenforschung, 206:1-140.

Weiler, W. 1943. Die otolithen aus dem Jung-Tertiär SüdRumäniens. I. Buglow und Sarmat. Senckenbergiana Lethaea, 26:87-115.

Weinfurter, E. 1952. Otolithen aus miozänen Brack- und Süßwasserschichten des Lavanttales in Kärnten. Sitzungsberichte der Österreichischen Akademie der Wissenschaften, Mathematisch-naturwissenschaftliche Klasse I, 161(2-3):141-148.

Weinfurter, E. 1954. Pisces, p. 30-41. In Papp, A. and Thenius, E. (eds.), Ein Lebensbild aus dem Pannon des Wiener Beckens. Mitteilungen der Geologischen Gesellschaft Wien, 46. 